\title{
Direct Economic Impact Analysis of the World's Top Five Busiest Airports in 2018
}

\author{
Sundaram Nataraja ${ }^{1}$ \& Robert Peterson ${ }^{2}$ \\ ${ }^{1}$ Central Washington University, Ellensburg, WA., USA \\ ${ }^{2}$ Yakima Air Terminal-McAllister Field, Yakima, WA., USA \\ Correspondence: Sundaram Nataraja, Professor of Aviation Management, Central Washington University, 400 E. \\ University Way, Ellensburg, WA, 98926, USA.
}

Received: October 9, 2019

Accepted: October 25, 2019

Online Published: October 31, 2019

doi:10.5430/ijba.v10n6p22

URL: https://doi.org/10.5430/ijba.v10n6p22

\begin{abstract}
The purpose of this study is to analyze the direct economic impacts of the world's top five busiest airports in 2018 as they contribute to the economic well-being of the larger communities they serve. This study uses a descriptive case-study methodology since the direct economic impacts of the world's top five busiest airports are going to be studied in a case-by-case with an intention of reporting the research findings that are not related to specific variables. Amongst the 17,678 commercial service airports in the world, Hartsfield-Jackson Atlanta International Airport (USA), Beijing Capital International Airport (Peoples Republic of China), Dubai International Airport (United Arab Emirates), Los Angeles International Airport (USA), and Tokyo Haneda International Airport (Japan) have been ranked respectively as the top five busiest airports in the world on the basis of passenger volume handled in 2018. The research findings indicate that these airports have tremendously benefited their respective communities in terms of employment generation, income generation, and total direct economic impacts. These airports have generated a total of $\$ 181.4$ billion worth of direct economic benefits to their respective communities and regions.
\end{abstract}

Keywords: direct economic impact, world's busiest airport, passenger volume, jobs created, income generated, economic benefits

\section{Introduction}

Statistics compiled by International Civil Aviation Organization in 2018 indicate that the aviation industry has seen dramatic growth over the past 20 years. The number of passengers travelling in 1998 had increased from 1.467 billion to 3.979 billion in 2017 (World Bank Group, 2018). In a report published in 2018, International Air Transport Association (IATA) confirms that aviation is growing, and that it is generating huge benefits to global communities. IATA also forecasts that a doubling of air passengers in the next 20 years could support 100 million jobs all around the world. Littorin (2015) states, "The connectivity that aviation brings is a key component in a globalized world" (p. 384). The airports, an essential element of the aviation industry, play a vital role in connecting various parts of the world and in driving the growth of international trade and associated benefits to global communities.

There are over 40,000 airports in the world available for various and specific uses. This number includes airports, aerodromes, air stripes, airfields and heliports/helipads. These airports are used for military purposes and civilian transportation and a majority of them are owned by their respective governments. Two broad categories of airports are (1) airports that are open to public use and (2) airports that are closed for public use. Based on the purpose and size of the airports, they can be further classified into five categories such as (1) Military airports, (2) Commercial service airports, (3) Reliever airports, (4) General aviation airports, and (5) Joint-use airports (available for both military and public use). This study focuses only on the commercial service airports. IATA publications (2014) indicate that there are 17,678 commercial service airports in the world and that almost one-third of them are located in the United States.

Several airports, as they are located in crucial parts of the world, serve as gateways to the entry of international passengers and facilitate travel to global markets, thus enable the mobility of people and products. Apart from assisting with mobility, airports help create significant economic benefits to their communities and beyond. Ensign (2014) articulates, "Airports can create distinct economic advantages for the regions they serve and greatly benefit 
businesses within those regions" (p. 23). The passengers' spending at these airports have resulted in multi-layer impacts to the respective communities where these airports are located. Specifically, the commercial services airports category makes huge economic impacts to their communities around the world. Therefore, analyzing the economic impacts of a specific airport is useful in understanding the benefits that an airport brings to its communities and region.

Prather (2015) enunciates that billions of passengers and billions of tons of cargo have been moved from point to point since the beginning of the aviation industry, which could not have occurred without airports. These airports are responsible for generating billions of dollars in economic benefits and supporting hundreds of thousands of jobs, thus, contributing to the economy and to the quality of life for people around the world. This study focuses on identifying and analyzing the direct economic impacts associated with the top five busiest airports of the world as per 2018 rankings of the world airports. While considering an airport as the busiest-airport, there are different methodologies that can be used, however, this study employs the passenger volume (the highest volume of passengers departed/enplaned and arrived/deplaned) at an airport as the method to measure the impacts.

The objectives of this study are to (a) explore the determining factors for an airport to be considered as the busiest-airport, (b) tag the type of economic benefits that an airport can make, (c) analyze the direct economic impacts of the world's top five busiest airports in 2018 as they contribute to the economic well-being of the larger communities they serve, and (d) identify the potential implications that this study would bring to the aviation industry and the academic communities which include aviation management and other business majors.

\section{Direct Economic Impacts of World's Top Five Busiest Airports in 2018}

\subsection{World's Top Five Busiest Airports}

Airports Council International (ACI) is the global trade representative of the world's airports. ACI develops standards, policies and recommended practices for airports, and provides information and training opportunities to raise standards around the world. According to ACI (2019), an airport could be called a busiest-airport based on three criteria (1) the usage of an airport by highest passenger volume (including the total passengers enplaned and deplaned in and out of commercial airlines including passengers in transit are counted once), (2) the handlings of the highest volume of air cargo traffic (including the loaded and unloaded freight and mail by mass carried by commercial air carriers), and (3) the usage of the airport runways by the highest number of aircraft movements (including take-offs, landings, and approach to the threshold).

For this study, the passenger volume has been considered as the criterion to determine an airport as "the busiest-airport." In a recent report published by USA Today, Mutzabaugh (2019) reports that Hartsfield-Jackson International Airport located in Atlanta, GA (USA) has been ranked as the busiest-airport in the world in support of that criterion. A set of two separate reports published by ACI (2019) and International Airport Review (2019) inform the details of the top five busiest airports in the world by passenger volume during the 2018 calendar year and the details are given in Table 1.

Table 1.

\begin{tabular}{llll}
\hline 2018 Rank & Name of the Airport & Location & Passenger Volume \\
\hline$\# 1$ & Jackson-Hartfield International & Atlanta, GA., USA & $107,394,029$ \\
\hline$\# 2$ & Beijing Capital International & Beijing, China & $100,983,290$ \\
\hline$\# 3$ & Dubai International & Dubai, UAE & $89,149,387$ \\
\hline$\# 4$ & Los Angeles International & Los Angeles, CA., USA & $87,534,384$ \\
\hline$\# 5$ & Haneda International & Tokyo, Japan & $87,131,973$ \\
\hline
\end{tabular}

Source: Airport Council International, (2019) and International Airport Review (2019)

Table 1 provides the passenger volume handled at these top five busiest airports of the world during 2018. According to ACI (2019). The passenger volume handled during 2018 at Hartsfield-Jackson international airport was 107.39 million, Beijing Capital international airport was 100.98 millions, Dubai international airport was 89.14 millions, Los Angeles international was 87.53 millions, and Haneda international was 87.13 millions. Hence, the global rankings as the busiest airports were given respectively based on the passenger volumes handled in 2018 . 


\subsubsection{Hartsfield-Jackson International Airport}

Hartsfield-Jackson International Airport (ATL) has been ranked as 'the busiest' airport in the world by passenger volume being handled since 1998. ATL is located in the city of Atlanta, which is in the state of Georgia, USA. ATL is spread over a total space of 4,700 acres; and has two terminals, 192 airline departure gates, and five parallel runways as of 2018. Since ATL is the primary hub of Delta Airlines, about $75 \%$ of the passengers who flew in and out of this airport used Delta Airlines services in 2018 (City of Atlanta, 2016-2019).

\subsubsection{Beijing Capital International Airport}

Beijing Capital International Airport (PEK), was the second busiest airport in the world and the busiest airport in China in terms of the passenger volume carried since 2010. It is located in the suburbs of Beijing, the capital city of the People's Republic of China. PEK has three terminals and three runways. Although PEK serves as the main hub for Air China; China Southern Airlines, Hainan Airlines, and China Eastern Airlines are also using the facilities to a greater extend. Air China is still the main operator of PEK serving to more than 120 destinations international destinations (Beijing, 2019).

\subsubsection{Dubai International Airport}

Dubai International Airport (DXB) was the third busiest airport in the world based on the passenger volume being handled in 2018. DXB is located in the city of Dubai in the United Arab Emirates. The strategic location of DXB is one of the prime reasons for its connectivity to more than 240 destinations across six continents through more than 100 commercial airlines' services (Dubai Airports, n.d.a). DXB is connecting Eastern Hemisphere to the Western Hemisphere. It consists of three terminals and two runways. Terminal 1 is designated to be Concourse D (D-Gates) from where all the international airlines are being operated. Terminal 2 is designated as Concourse F (F-Gates) which serves for reginal and international flights. Terminal 3 (T3) is the second largest-building in the world in terms of floor space and largest airport terminal. T3 consists of A, B, and C Concourses (A-Gates, B-Gates, and C-Gates) and all these Gates are used exclusively by Emirates and Qantas Airways operations. Concourse A in T3 is the world's first largest purpose-built A380 facility and it is used exclusively by Emirates Airlines (Dubai Airports, n.d.b). Concourse $\mathrm{E}$ houses 90 counters for Immigration services for both departing and arriving passengers. Also, there are 10 counters and $4 \mathrm{E}$ Gates ate made available for providing exclusive services to First and Business Class passengers.

\subsubsection{Los Angeles International Airport}

Los Angeles International Airport (LAX) was the fourth busiest airport of the world by passenger volume handled in 2018. LAX is located in the city of Los Angeles, CA. Since it is the largest international airport in the West Coast of the United States, it serves as the major gateway to people travelling to and from several destinations. More specifically, LAX is known as the premier "Gateway to the Pacific Rim" for its deep connections to Latin America and Asia (Los Angeles Airport, 2019). It has nine terminals and four parallel runways. LAX is offering 692 daily flights to 85 U.S. cities and 928 weekly nonstop flights to 67 cities in 34 countries via 59 airlines. It serves as a hub for American Airlines, Delta Airlines, Alaska Airlines, and United Airlines. At the same time, Air New Zealand, Qantas Airways, Allegiant Air, Volaris, Spirit Airlines, and Southwest Airlines are the air carriers that mainly use the facilities and infrastructure of LAX (Los Angeles Airport, 2019).

\subsubsection{Tokyo Haneda Airport}

Tokyo Haneda International Airport (HND) was the fifth busiest airport in the world in terms of passenger volume handled in 2018. Although HND was serving both domestic and international flights prior to 1978, the primary role of HND was changed to handle almost all scheduled domestic flights and charter flight operations only because Narita International Airport was opened in 1978 to serve the international traffic. However, HND started to handle more international flight in 2010 with the completion of a new runway and a new international terminal building (Haneda Airport, 2019). HND is located in Ota, Tokyo, which is 14 KM south of Tokyo Station. HND has three terminal buildings and four runways.

\subsection{Economic Impacts of an Airport}

Airports bring greater economic impacts, and hence benefits, to the communities and regions to which they serve. They are a part of the indispensable infrastructure for a wide range of economic activities (Cervinka and Tykva, 2012). The economic impacts created by airports are universal in nature. Torok and Heinitz (2013) articulate that air transportation has a positive effect on national economies such as increasing the standard of living since the airports facilitate travel to global markets and enable the mobility of people and products. Prather (2015) believes that it is 
important for airports to conduct economic impact analysis so that these impacts can be quantitatively determined and shared with the local community and such information sharing is a worthwhile attempt for rebuilding the communities economically stronger. Along these lines, many state aviation organizations hire consultants to determine the economic impact of each airport. For example, the Washington State Department of Transportation (WSDOT) Aviation Division, with the support of the Federal Aviation Administration (FAA) is currently in the process of conducting an economic impact study in order to measure the economic impacts of each public-use airport in the state of Washington. This will help to assess the economic value that the airports in the state of Washington could create for their communities (WSDOT, 2019).

Kersley (2010) endorses that economic appraisal of the larger projects (such as airport infrastructure development) would help to quantify the potential contribution of these projects toward new jobs and economic productivity to a specific community. Martin Associates (2019), a leading economic and transportation consulting firm, classifies economic impacts of an airport into four categories: (1) Revenue Impacts, (2) Employment Impacts, (3) Income Impacts, and (4) Tax Impacts. Air Traffic for Germany Initiative that was formed in 2006 claimed in its master plan that one million additional passengers handled by a specific airport will create 1,000 jobs every year at German airports (Klophaus, 2007). Additionally, research literatures indicate that once an airport is operational, it pumps money into the local economy through the staff that it employs and the activities of the airlines that use the airport (Button, Doh, \& Yuan, 2010).

Since an airport is a diverse economic system, the study focuses on measuring the direct economic impacts of the selected airports. To make it simple, this study has adapted a model suggested by the Colorado Department of Transportation - Aeronautics Division and the model is shown in Figure 1 below.

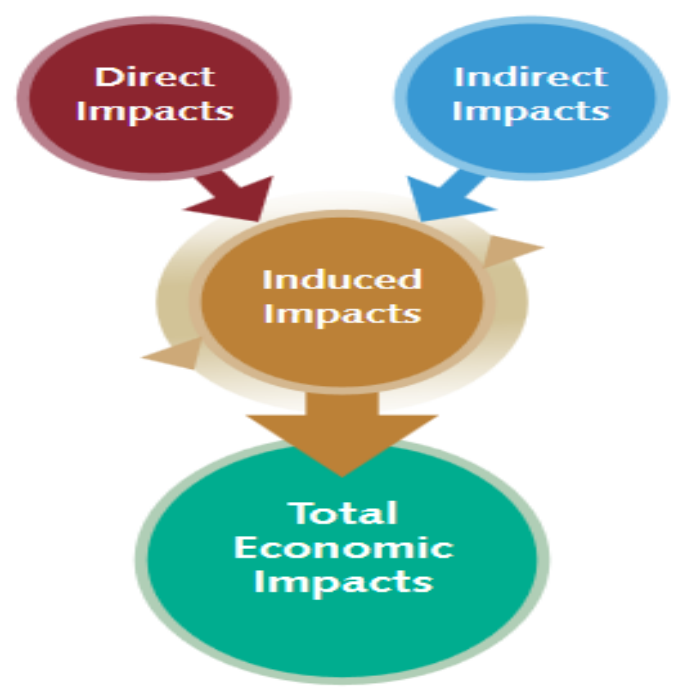

Figure 1. Airport economic impact analysis model

Source: Colorado Department of Transportation - Aeronautics Division (2008).

Figure 1 illustrates the pattern for analyzing the economic impact of a specific airport into four categories as shown in the adapted model: (1) direct impacts, (2) indirect impacts, (3) induced impacts, and (4) total economic impacts.

\subsubsection{Direct Economic Impact of an Airport}

The direct economic impacts are the start of the economic impact cycle and they refer to the first round of spending and these are directly generated from/at the airport itself. It can be measured through (a) the number of employees being employed at the airport communities, (b) the amount of salaries and wages being paid to the employees/staff, and (c) the amount of income being generated through various economic/business activities that were carried out at a specific airport that is being studied. Prather (2015) explains:

Direct economic impacts consist of the amount of spending that will remain within the local economy, the indirect economic impacts refer to the result when a business makes purchases from other businesses, and the induced economic impacts result from the expenditures of employee wages. (p. 549) 
The Economic Impact Study Report (2008) published by the Colorado State Department of Transportation (DOT)Aeronautics Division explains:

Direct impacts are related to each airport, its operation, and the provision of aviation services. Indirect impacts are those associated with visitor spending; these impacts take place off-airport. Induced impacts are those associated "spin-offs" from direct and indirect impacts. When a person employed at an airport uses their paycheck to purchase goods and services, they support additional jobs, payroll, and annual economic activity. As the economic cycle that starts with the airports and visitors who arrive via the airports continues to re-circulate or multiply, additional induced economic impacts are created. Together, direct, indirect, and induced impacts equal each airport's total annual economic impacts. (p. 2)

In addition to Colorado State DOT's explanation, South Carolina Aeronautics Commission (2018) further explains this concept as follows:

When a "direct" airport employee uses his or her payroll to buy groceries, pay for child care, or take their family pet to a local veterinarian, the direct airport-related payroll is being infused into other sectors of the economy, creating indirect/induced economic impacts. Indirect impacts are most often associated with multipliers in the industrial, distribution, professional services, or utility sectors of the economy. Induced impacts are most often associated with multiplier impacts in the retail and service sectors of the economy. (p. 9)

In summary, the economic impacts created by an airport can be measured at a multi-layer level, however, this study focuses on the direct economic impacts only.

\section{Research Methodology and Data Analysis}

\subsection{Research Methodology}

This study uses a case-study methodology since the direct economic impacts of the world's top five busiest airports are going to be studied case-by-case. Yin (1994) categorizes the case-studies into three types: (1) exploratory, (2) explanatory, and (3) descriptive. Exploratory case is for searching without first defining specific variables, explanatory case is for searching after defining specific variables, and descriptive case is for reporting on findings not related specific variables. Since the economic impact analysis of the top five busiest airports is written with an intention of reporting the research findings that are not related to specific variables, this study is called a descriptive case-study. Additionally, a case-study research methodology has been opted for this study because it facilitates an in-depth understanding of a current complex issue and strengthens previous knowledge, while providing opportunities for further research (Johnson, 2009).

\subsection{Data Analysis}

Although four types of economic impacts can be studied, only the direct impacts are being analyzed in this study due to the limitations in collecting international level data pertinent to other economic impacts. Broadly speaking, Figure 2 illustrates the content analysis of the direct economic impacts generated at the world's top five busiest airports:

Identifying the total number of employees at the top five busiest airports

Categorizing and counting the amount of salaries and wages being paid to the employees/staff

Categorizing and counting the amount of income being generated through various economic/business activities that were carried out at the specific airport

Analyzing the total direct economic impacts generated at each one of the top five busiest airports

Correlating the direct economic impacts of the world's top five busiest airports with each other

Figure 2. Content analysis of the direct economic impacts 
Figure 2 explains how the data pertinent to direct economic impacts have been analyzed in a systematic order.

\section{Findings and Discussion}

The analysis of the direct economic impacts that the world's top five busiest airports have generated has begun by identifying the total number of employees working at the top five busiest airports in 2018. Table 2 provides the details of the number of employees.

Table 2.

\begin{tabular}{llll}
\hline Airport Code & Airport Operations Staff $\left(\&^{*}\right)$ & Support Services Staff $\left(\&^{* *}\right)$ & Total Jobs \\
\hline ATL $*$ & 63,000 & 448,000 & 511,000 \\
\hline PEK $^{* *}$ & 49,640 & 52,372 & 102,012 \\
\hline DXB*** & 90,000 & 416,500 & 490,000 \\
\hline LAX**** & 59,000 & 566,000 & 625,000 \\
\hline HND***** & 47,295 & 216,784 & 264,079 \\
\hline
\end{tabular}

Sources:

* Comprehensive Annual Financial Report. City of Atlanta, Department of Aviation. (2019).

** Aviation Benefits Beyond Borders (2018)

*** Dubai Economic Report 2018 (2019)

**** Airport LA (2019)

***** Travel Voice - Japanese Travel Trade News (2019)

\&* Airport Operations Staff include personnel involved in performing services inside of the airport fence and at the terminal

\&** Support Services Staff include personnel involved in performing services outside of the airport such as car rentals, hotels, restaurants, shops, gas stations, etc.

Table 2 shows the number of employees working at the world's top five busiest airports in 2018 with breakdowns of three categories such as (a) employees directly engaged in airport operations, who involved in performing services inside of the airport fence and at the terminal, (b) employees involved in airport support services such as car rentals, hotels, restaurants, shops, gas stations, etc. and (c) the total jobs generated in those specific airports.

It can be noted that PEK has generated only a total of 102,012 jobs to manage the second highest passenger volume $(100,983,290)$ traveled at a single airport in 2018. At the same time, ATL has generated 511,000 jobs to manage the highest passenger volume $(107,394,029)$ traveled at a single airport in 2018. Just for an additional volume of approximately 6.4 million passengers, ATL has generated 408,988 more jobs in 2018. Again, it can be noted that the level of quality services provided at these airports may vary apart from the total number of passengers being handled.

Table 3 exemplifies the categorization and the amount of salaries and wages being paid to the employees/staff working at these airports in 2018.

Table 3.

\begin{tabular}{llll}
\hline Airport Code & Airport Operations Staff & Support Services Staff & Total \\
\cline { 2 - 4 } & Salaries/Wages & Salaries/Wages & Salaries/Wages \\
\cline { 2 - 4 } & Paid (in billion) & Paid (in billion) & Paid (in billion) \\
\hline ATL $*$ & $\$ 3.15$ & $\$ 17.92$ & $\$ 21.07$ \\
\hline PEK** & $\$ 0.99$ & $\$ 0.63$ & $\$ 1.62$ \\
\hline DXB*** & $\$ 5.35$ & $\$ 9.37$ & $\$ 14.72$ \\
\hline LAX $* * *$ & $\$ 4.13$ & $\$ 29.43$ & $\$ 33.56$ \\
\hline HND**** & $\$ 2.46$ & $\$ 8.93$ & $\$ 11.39$
\end{tabular}

* Comprehensive Annual Financial Report. City of Atlanta, Department of Aviation. (2019). 
** Aviation Benefits Beyond Borders (2018)

*** Dubai Economic Report 2018 (2019)

**** Airport LA (2019)

***** Travel Voice - Japanese Travel Trade News (2019)

Table 3 provides the amount paid in salaries and wages to the staff engaged in airport operations and support services in each of the top five busiest airports in 2018. Also, total amount of salaries and wages paid to staff involved in both airport operations and support services such as car rentals, hotels, restaurants, shops, gas stations, etc. It can be noted that the amount of salaries and wages paid in PEK airport is substantially low due to the availability of low cost employees there. Also, it can be noted that the salaries and wages paid in ATL, DXB and LAX airports are high due to high cost paid to the employees and staff working in those airports, probably because of the high cost of living in those cities. Whereas the amount of salaries and wages paid in HND airport seems to be staying at the medium level.

Table 4 provides the dollar value for the amount of income being generated through various economic/business activities that were carried out at the specific airports in 2018.

Table 4.

\begin{tabular}{llll}
\hline Airport Code & Salaries/Wages paid & Income generated & Total Direct Economic \\
\cline { 2 - 4 } & paid (in billions) & (in billions) & Impacts (in billions) \\
\hline ATL $*$ & $\$ 21.07$ & $\$ 13.73$ & $\$ 34.8$ \\
\hline PEK** & $\$ 1.62$ & $\$ 4.98$ & $\$ 6.6$ \\
\hline DXB*** & $\$ 14.72$ & $\$ 11.98$ & $\$ 26.7$ \\
\hline LAX**** & $\$ 33.56$ & $\$ 26.54$ & $\$ 60.1$ \\
\hline HND***** & $\$ 11.39$ & $\$ 41.81$ & $\$ 53.2$ \\
\hline
\end{tabular}

Sources:

* Comprehensive Annual Financial Report. City of Atlanta, Department of Aviation. (2019).

** Aviation Benefits Beyond Borders (2018)

*** Dubai Economic Report 2018 (2019)

**** Airport LA (2019)

***** Travel Voice - Japanese Travel Trade News (2019)

Table 4 carries the numbers that categorize the salaries and wages paid; income generated through various economic and business activities such as consultancy services, construction of road, water supply, health and other basic needs; and the total amount of direct economic impacts created at these top five busiest airports of the world in 2018. It can be noted that the salaries and wages paid for staff were lower than the income generated in both PEK and HND airports. At the same time, the salaries and paid to staff were higher than the income generated through various economic/business activities in ATL, DXB, and LAX airports in 2018. These variations were found to be the higher labor cost in those respective regions.

Figure 3 correlates the direct economic impacts of the world's top five busiest airports in 2018 with each other. 


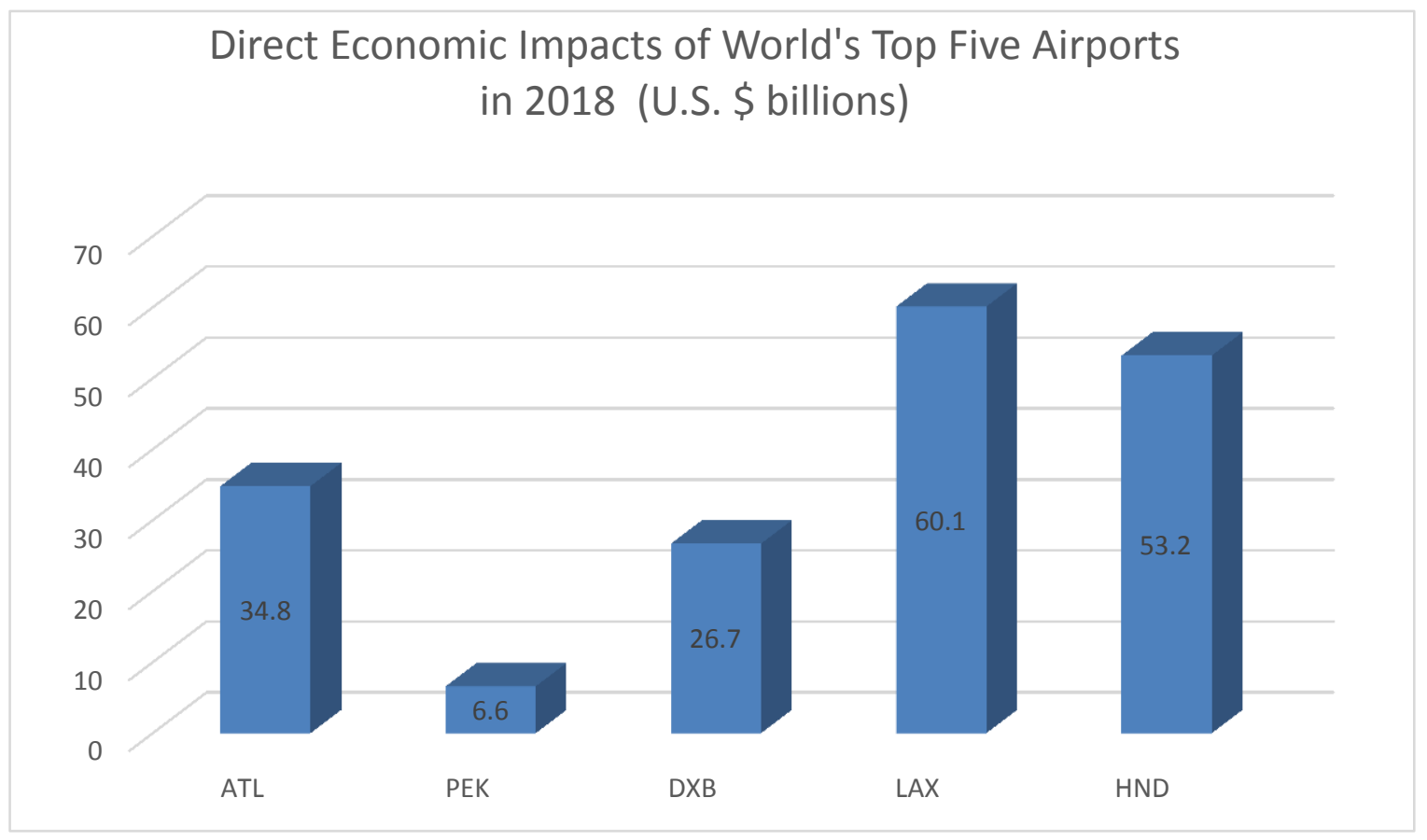

Figure 3 .

It can be noted from Figure 3 that LAX airport is the highest direct economic benefits generator out of the top five busiest international airports in 2018. HND airport stands out to be the second highest direct economic impacts generator in this list of five airports in 2018. ATL and DXB have come as the third and fourth in generating a higher amount of direct economic benefits to their communities and the region for this time period. It is interesting to note that PEK airport has generated the least amount of direct economic impacts in 2018 despite the fact that it was the second busiest airport of the world in 2018 in term of the highest passenger volume being handled.

\section{Research Implications}

This research is expected to have two implications. The first one is that it would help inform the readers of this article about the potential of an international airport in terms of the tremendous economic benefits it generates to its communities and the regions. The second implication is to inform and induce the readers of this article about more opportunities to replicate this research in order to conduct even more in depth research to find out all the layers (such as direct impacts, indirect impacts, and induced impacts) of the economic impact to portray a full and big picture on the total benefits generated by these airports.

\section{Conclusion}

The study has focused on identifying and analyzing the direct economic impacts associated with the world's top five busiest airports as per the 2018 rankings. Although there were different methodologies that can be used to consider an airport as the busiest-airport, this study has used the passenger volume (the highest volume of passengers departed/enplaned and arrived/deplaned) at an airport as the method to measure the direct economic impacts.

This research study proved to be significant since there is not a comprehensive study and analyses are found to be available on both online databases and physical libraries as of now (2019). Especially, this study has collected the most recent (2018) information and data pertaining to passenger volumes handled and the direct economic impacts made at these busiest airports.

Public's perception of airports may vary based on the individual's viewpoint. Generally, people view airports as they provide access to nation's air transportation system and facilitate the movement of passengers and cargo from one place to another. However, not everyone views an airport favorably. Many people see airports as a nuisance to communities and believe airports are major source for noise pollution, which is a major community annoyance; air pollution; and water pollution, including point-source discharges of industrial process water, noncontact cooling 
water, and collected or channeled stormwater runoff. Although airports may and can cause inconvenience to communities, they generate enormous economic value to the same communities.

This study has found the world's top five airports alone have generated a total of $\$ 181.4$ billion worth of direct economic benefits to their respective communities and regions in 2018. Based on these statistics, it is unimaginable to the massive economic benefits the remaining $(17,673)$ airports in the world could generate every year. At the same time, it should be noted that each airport has its own potential and limitations in generating economic impacts.

Additionally, these five airports alone have helped 472.2 million people to be transported to their destinations, while they have generated 1,992,091 direct employment in 2018. The statistical information compiled through this research study is believed to be significantly useful to the general public to make necessary corrective adjustments to their perception about airports in the future. Moreover, the study findings are expected to be a great source of information for the aviation industry professionals around the globe; students, who are studying in the international business, aviation management, and other disciplines, to understand the theories and concepts presented in their programs of study as well as who are aspiring to become airport managers; and the researchers, who are interested in replicating this study.

\section{References}

Airport Council International. (2019). Annual traffic data. Retrieved June 30, 2019, from https://aci.aero/data-centre/annual-traffic-data/

Airport Council International. (2019). World's 20 Busiest Airports. Retrieved June 30, 2019, from https://aci.aero/wp-content/uploads/2019/03/2486_Top-20-Busiest- Airport_passenger_v3_web.pdf

Airport LA. (2019). General Information/Economics. Retrieved July 3, 2019, from https://www.airport-la.com/info/airport.html

Aviation Benefits Beyond Borders. (2018). Retrieved July 4, 2019, from https://aviationbenefits.org/media/166344/abbb18_full-report_web.pdf

Beijing Capital Airport. (2019). Guide to Beijing Airport (PEK). Retrieved July 3, 2019, from https://www.beijing-airport.com/

Button, K., Doh, \& Yuan, J. (2010). The role of small airports in economic development. Journal of Airport Management, 4(2), 125-136.

Colorado Department of Transportation - Aeronautics Division. (2008). Economic Impact Study Report. Retrieved June 30, 2019, from http://hermes.cde.state.co.us/drupal/islandora/object/co\%3A10962/datastream/OBJ/view

Cervinka, M., \& Tykva, T. (2012). The relation between air transport and selected aspects of the regional economy. Scientific Papers of the University of Pardubice. Series D, Faculty of Economics \& Administration, 18(24), $31-42$.

City of Atlanta. (2016-2019). ATL Fact Sheet. Retrieved July 3, 2019, from https://www.atl.com/about-atl/atl-factsheet/

Dubai Airports. (n. d.). Dubai International (DXB). Retrieved July 3, 2019, from https://www.dubaiairports.ae/corporate/about-us/dubai-international-(dxb)

Dubai Airports. (n. d.). Flight Connections. Retrieved July 4, 2019, from https://www.dubaiairports.ae/before-you-fly/procedures/flight-connections

Dubai Economic Report. (2018, 2019). Retrieved July 8, 2019, from http://www.dubaided.ae/StudiesAndResearchDocument/Dubai-Economic-Report-2018-Full-Report.pdf

Ensign, L. (2014). Airports and regions: The economic connection. Economic Development Journal, 13(2), 23.

Haneda Airport. (2019). Haneda Unofficial Airport Guide. Retrieved July 8, 2019, from http://www.haneda-airport.com/

International Air Transport Association. (2018). IATA Forecast Predicts 8.2 billion Air Travelers in 2037. Retrieved June 30, 2019, from https://www.iata.org/pressroom/pr/Pages/2018-10-24-02.aspx

International Airport Review. (2019). The top 20 largest airports in the world by passenger number. Retrieved June 28, 2019, from https://www.internationalairportreview.com/article/32311/top-20-largest-airports-world-passenger-number/ 
International Airport Review. (2014). Annual Review of 2014. Retrieved June 28, 2019, from https://www.iata.org/about/Documents/iata-annual-review-2014.pdf

Johnson, J. (2009). Case study methodology in the Aviation industry. Journal of Aviation/Aerospace Education \& Research, 18(3). Retrieved July 2, 2019, from https://doi.org/10.15394/jaaer.2009.1427

Kersley, H. (2010). An alternative methodology for evaluating airport expansion with particular focus on Heathrow. Journal of Airport Management, 5(1), 19-33.

Klophaus, R. (2007). The impact of additional passengers on airport employment: The case of German airports. Journal of Airport Management, 2(3), 265-274.

Littorin, H. (2015). Catalytic effects of aviation and their importance for airport development. Journal of Airport Management, 9(4), 384-389.

Los Angeles Airport. (2019). Guide to Los Angeles Airport - LA Airport. Retrieved July 4, 2019, from https://www.los-angeles-airport.com/

Martin Associates. (2019). Airport Economic Impact Studies. Retrieved July 14, 2019, from https://martinassoc.co/services/

Mutzabaugh, B. (2019). The world's busiest airport?. Retrieved June 27, 2019, from https://www.usatoday.com/story/travel/flights/todayinthesky/2019/03/13/worlds-busiest- airport

Prather, D. (2015). Airport Management. Newcastle, WA: Aviation Supplies \& Academics, Inc.

South Carolina Aeronautics Commission (SCAC). (2018). Economic Impact Technical Report. Retrieved from www.scaeronautics.com/download/2018_Economic_Impact_Technical_FinalReport.pdf

Travel Voice. (2019). Japanese Travel Trade News. Retrieved July 3, 2019, from https://www.travelvoice.jp/english/haneda-airport-may-generate-an-economic-effect/

Torok, A., \& Heinitz, F. (2013). Economic impacts on destination air traffic following a flag carrier's market exit: A case study for Budapest. Aviation, 17(4), 161-169. https://doi.org/10.3846/16487788.2013.861226

Washington State Department of Transportation (WSDOT). (2019). Economic Impact Study. Retrieved August 24, 2019 from https://www.wsdot.wa.gov/aviation/Planning/

World Bank Group. (2018). International Civil Aviation Organization, Civil Aviation Statistics of the World. Retrieved June 19, 2019, from https://data.worldbank.org/indicator/IS.AIR.GOOD.MT.K1

Yin, R. (1994). Case Study Research: Design and Methods (2nd ed.). Thousand Oaks, CA: Sage Publishing. 